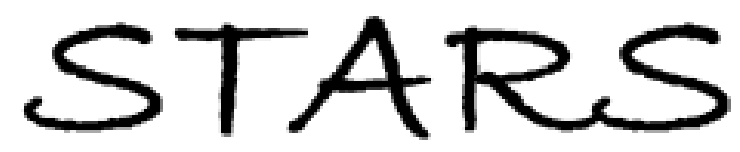

University of Central Florida

STARS

2018

\title{
The Pay Equity Dilemma Women Face Around The World
}

Lana D. McMurray

University of Central Florida

Part of the Business Administration, Management, and Operations Commons

Find similar works at: https://stars.library.ucf.edu/honorstheses

University of Central Florida Libraries http://library.ucf.edu

This Open Access is brought to you for free and open access by the UCF Theses and Dissertations at STARS. It has been accepted for inclusion in Honors Undergraduate Theses by an authorized administrator of STARS. For more information, please contact STARS@ucf.edu.

\section{Recommended Citation}

McMurray, Lana D., "The Pay Equity Dilemma Women Face Around The World" (2018). Honors

Undergraduate Theses. 372.

https://stars.library.ucf.edu/honorstheses/372

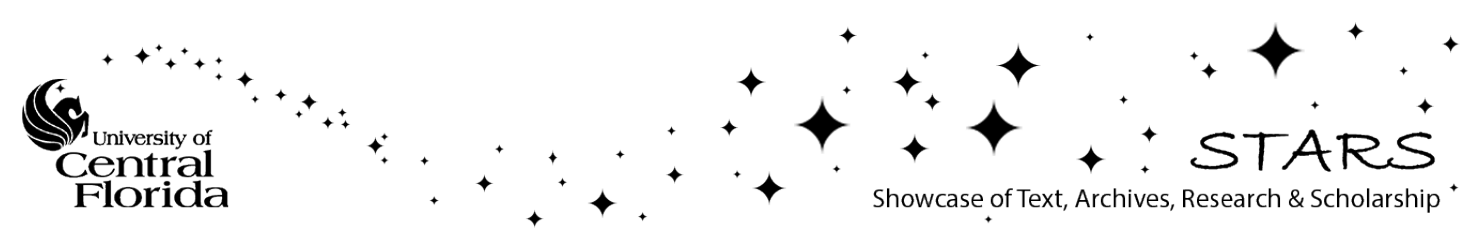


THE PAY EQUITY DILEMMA WOMEN FACE AROUND THE WORLD

by

\section{LANA D MCMURRAY}

A thesis submitted in partial fulfillment of the requirements

for the Honors in the Major Program in Marketing

in the College of Business

and in the Burnett Honors College

at the University of Central Florida

Orlando, Florida

Summer Term, 2018

Thesis Chair: Muge Yayla-Kullu, PhD 


\begin{abstract}
In this research, I examine the pay equity dilemma women face around the world and how it is different in various regions of the world. My research question focuses on "how a nation's cultural characteristics affect pay equity?" It is already documented that men are paid more than women. The goal of this study is to explain how individual characteristics of national culture (such as masculinity, individualism, power distance, and uncertainty avoidance) impacts this inequality. By increasing the understanding of pay inequality, changes can be made that will improve the lives of not just women but the families of those women and the world overall. We use data from Geert Hofstede's national culture dimensions and the Global Gender Gap Report by the World Economic Forum. Our results suggest that gender gap reduces in low power distance cultures, in high individualistic cultures, in low masculine cultures, and in low uncertainty avoidance cultures. Our results provide evidence that the economic prosperity of women around the world is significantly impacted by cultural dimensions.
\end{abstract}




\section{DEDICATION}

For my children,

Ebony, Marcia, Kristian, and Nathaniel,

my power to keep moving forward comes from

my love for you. 


\section{ACKNOWLEDGMENTS}

I wish to express the deepest gratitude to all of my life's mentors who have enabled me to reach this point. First and foremost, I would like to thank Dr. Muge Yayla-Kullu for her inestimable guidance, support, and encouragement. I am very thankful to her for sharing her immense

knowledge in research and precious time. Additionally, I was privileged to draw on the expertise of Dr. Andrew Johnson to participate in this research project. Finally, thank you to Doctoral Student, Lam An for the support with Excel, and Matt DeSalvo and Jason Delaney at the University of Central Florida's LibTech desk in the Library for helping me resolve my technical issues.

I would also like to express a special thank you to Mel and Renee King, we became family through marriage but you became my real family through love. Thank you for your support and for always believing in me. 


\section{TABLE OF CONTENTS}

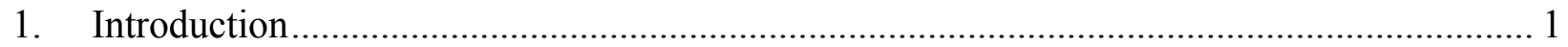

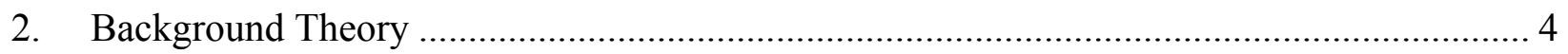

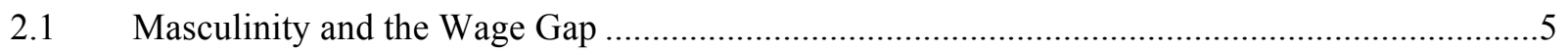

2.2 Individualism/Collectivism and the Wage Gap............................................................

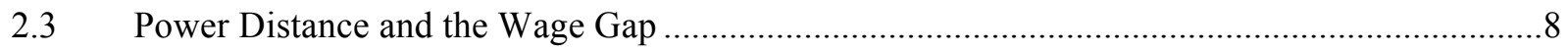

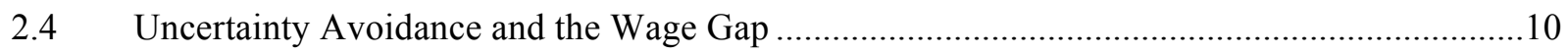

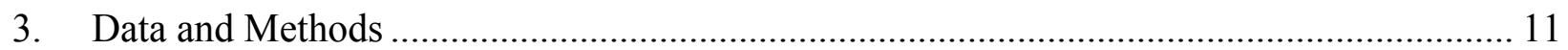

3.1 Geert Hofstede's Framework for Assessing Culture ...........................................................11

3.2 The Global Gender Gap Report 2016 - World Economic Forum...........................................12

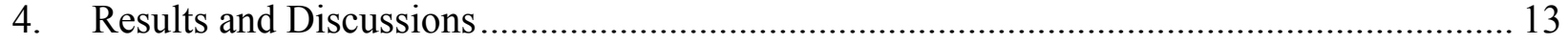

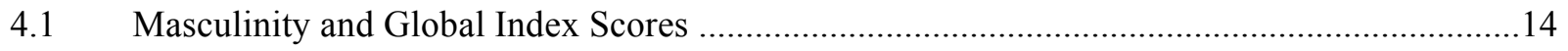

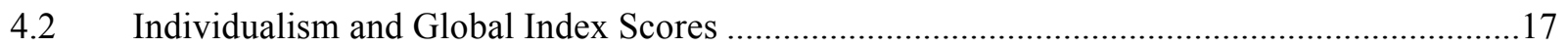

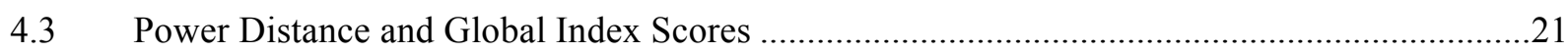

4.4 Uncertainty Avoidance and Global Index Scores ................................................................24

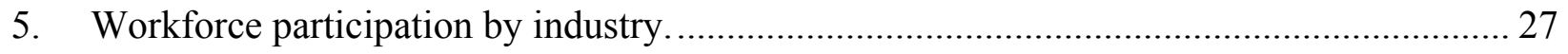

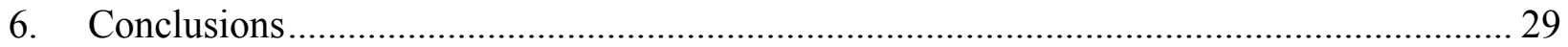

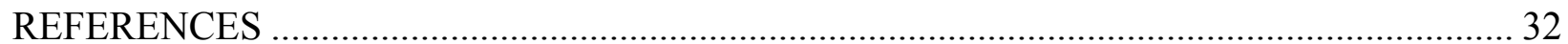




\section{LIST OF TABLES}

Table 1: Summary of Research Output.............................................................................. 13 


\section{LIST OF FIGURES}

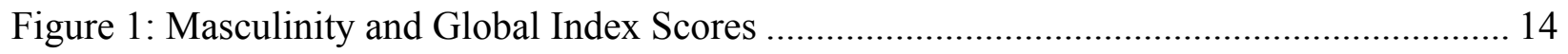

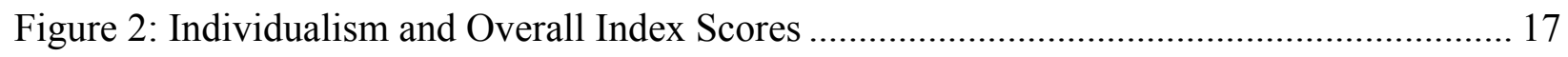

Figure 3: Power Distance and Overall Index Scores ......................................................... 21

Figure 4: Uncertainty Avoidance and Overall Index Scores ............................................ 24

Figure 5: Gender gap and female share of customer base, by industry ................................ 27

Figure 6: Women's workforce participation, by industry ............................................... 28 


\section{Introduction}

"The gender wage gap has now been intensively investigated for a number of decades, but also remains an area of active and innovative research" (Blau and Kahn 2017 p. 789). Evidence demonstrates that the gender pay gap exists and is a complicated issue that can't be dismissed with the notion that women's personal choices or low self-esteem are the root cause. "Of the current 19-cent gender wage gap, 41 percent (or about 8 cents) remains unexplained. In other words, 41 percent of the difference in pay between men and women has no obvious measurable rationale" (Carnevale et al., 2018). Women face discrimination in the work place and as would be expected, numerous efforts are being applied to correct the inequality. Yet despite the attempts to resolve this issue, The World Economic Forum 2017 index reports that the global gender gap is increasing and is going to take 217 years to close, (Brinded 2017). Also, "Globally, women are paid less than men. Women in most countries earn on average only 60 to 75 per cent of men's wages." (Facts and Figures 2017), why is nothing seemingly working? Could national culture be the reason? How would a nation's cultural characteristics affect pay equity?

The goal of this study is to explain how individual characteristics of national culture such as masculinity, individualism, power distance, and uncertainty avoidance impact the gender pay gap. We explore the social mechanisms that can explain the inequity. The result of this study is to provide an understanding of these social dimensions to increase awareness of cultural barriers that hold women down and uncover strategies that can aid women in reaching economic empowerment. 
April 4th, Equal Pay Day, marks the amount of time it takes for women to reach what men earned in the previous year. It's 55 years since the enactment of the Equal Pay Act in the United States and as of 2017, women are still earning 82 cents for every dollar a man earns. (Fortune 2017). This law was passed the same year that University of Central Florida was founded, in 1963, and at that time the gender gap was 54 cents for every dollar a man earns.

I have personally witnessed discrimination in the workplace. I watched my coworker, a senior employee of more than 25 years be turned down for a management role in the department she'd dedicated her time to. I watched this brilliant woman get pressured to train the inexperienced male who was hired instead of her. She was shamed for not wanting to help him and made to feel that she would not be a team player if she didn't. She was demoralized, as was I.

His new office space was directly next to mine. It was incredibly frustrating for me to listen to him complain, unashamedly about how the job was completely new to him and he didn't understand anything we did. "Why was he hired and not her?" I thought to myself. Yet he was given the opportunity to learn on the job whereas my coworker, her experience wasn't enough. My coworker did report this experience to the Human Resources Department but the response was pathetic. They increased her title to VP which gave her some additional benefits and added a modest bump to her salary but her request to know why she was passed over for the promotion went unanswered. The truth is, this wasn't just about the money for her, this was an opportunity for her growth and development and more importantly an opportunity for advancement that could increase her ability to achieve her economic potential. 
Experiences like this happen every day. In fact, per the 2017 Women in the Workplace study by LeanIn.Org and McKinsey \& Company, "for every 100 women promoted past entry level positions, 130 men are promoted (Getting to Gender Equality 2017), Clearly men and women are not moving at the same promotional pace.

Carol Sankar, negotiation trainer, leadership advisor, and founder of The Confidence Factor For Women, reports that she is asked a routine question by women at her numerous training and speaking events. "Don't you think I should wait a few more years before asking for a raise?" Carol explains how this reflects the feelings of doubt and of under-qualification that permeates the thoughts of women in middle and senior level roles. (Sankar 2017) That was a true case for my friend.

A study by Glassdoor showed that $68 \%$ of women accept the salary they offered compared to men at 52\% per a survey (Chamberlain et al., 2016). These thoughts and attitudes are not just individual personality traits, but culturally derived characteristics embodied by the inhabitants.

The gender wage gap is not unique to the United States. Women the world over are affected by wage inequality. In 2016, thousands of women in Iceland left work 14 minutes early in an orchestrated effort to protest their 14 percent gender wage gap. At that time, the wage gap was 72 cents to every man's dollar (Fortune 2017). Less than a month later France followed suit protesting their 15.1 percent gender wage gap. (Center for American Progress 2017).

Discrimination alone is not the only reason women fail to be paid the same as men. Wage inequality has many contributing factors, the motherhood penalty, lack of negotiation skills, limited work experience, housework, the treatment of female based jobs compared to male 
dominated roles, to name a few. However, focusing solely on these problems ignores other factors at work within the gender pay gap such as cultural norms. The primary focus of our study will be on the impact cultural norms have on the gender wage gap women face throughout the world.

\section{Background Theory}

It's common knowledge that every nation has its own distinct way of expressing itself. It's a collective display of personality that we call culture. What is not commonly known is the influence culture plays in the gender wage gap. Can women living in different countries expect their salaries to be lower because of the culture they live in? Do specific dimensions reduce women's pay gap?

Social psychologist Geert Hofstede (1980), pioneered research on cross-cultural groups. However, in his ground-breaking study, he developed a theory that organized the behavior of society into a framework known as Hofstede's cultural dimensions' theory. Hofstede (1980) said that "Collective mental programming of people in different cultures exists." He also referred to culture as the "software of our minds. What we share with those around us" (Hofstede 1980). In his study six common cultural dimensions are identified. In this research, we will examine the impact of four on wage inequality: masculinity/femininity, Individual/collective, power distance, and uncertainty avoidance.

What Hofstede's (1980) research found was that people gathered in the same geographic location share unwritten rules. This group think is the foundation of the programming that is passed down from childhood and forms cultural societies. How we learned to see the world affects us as a group not at the individual personality level. 
Hofstede (1980) found the four dimensions of national culture using a single questionnaire, one of the largest known to date at that time. More than 116,000 questionnaires were collected from employees at IBM a large U.S. based multinational corporation in 40 countries around the world between 1967 and 1973. He devised a cross-country comparison of the assumptions and values and ascribed each country a numerical value on a 100-point scale called an index. The naming convention is specific for each dimension its associated. This scale provides a comparative perspective to examine different cultures - Masculinity Index (MAS), Individualism Index (IDV), Power Distance Index, (PDI), and Uncertainty Avoidance Index (UAI).

Geert Hofstede's definition of the dimension of societal culture are described below. These will be used in this research to shed light on the difference in women's work pay.

\subsection{Masculinity and the Wage Gap}

MAS is the extent to which the use of force is endorsed socially. In a masculine society, men are supposed to be tough. Men are supposed to be from Mars, women from Venus. Winning is important for both genders but achieving is especially important in masculine cultures. Quantity is important and big is beautiful. In a feminine society, the genders are emotionally closer. Competing is not so openly endorsed, and there is sympathy for the underdog. This dimension is related to the division of emotional roles between women and men. This is not about individuals, but about expected emotional gender roles. Masculine societies are much more openly gendered than feminine societies (Hofstede 1980).

Of all the Hofstede dimensions, masculinity seems the easiest to understand. Assignment of gender roles is second to nature seemingly and readily accepted. Yet this dimension like the 
others means more than what is assumed. Yes, a country with high masculinity expresses itself as competitive and showy but the decisive and assertive traits are necessary for everybody.

In global gender pay inequality, labor markets are explained to have two key margins. 1. Pure discrimination where women are paid less for the same work of equal value. 2. Differences in value created due to occupational choice (Rockey 2017). Considering Hofstede's dimension of masculinity where women's and men's roles are clearly defined and enforced, this attitude would suggest the reason why jobs that are predominantly occupied by females are paid less than male centered roles is the cultural perception of women and men.

Regarding differences due to occupational choice, how much does household production gender-induced roles play into earnings? Namely family responsibility. It's exhausting to care for children, a husband and keep a house. My own prior thinking which resulted in my graduating as an older student was due to a subscription to a high masculine societal group. I sacrificed my wants and needs for the good of my husband and children. I felt that it was wrong for me to place my children in daycare to be raised by strangers while I went to work. Also it was cheaper for me to stay home than go to work. The expense of the in-group disapproval, my own guilt and condemnation along with childcare expenses, were costs I felt I'd incur for straying from my feminine role as the nurturer. In hindsight, these attitudes I adopted were more attributable to culture than my original thoughts.

On the flip side Claire Cain Miller describes an interesting phenomenon involving the feministic culture in Scandinavia, "Despite generous social policies, women who work full-time there are still paid 15 percent to 20 percent less than men, new research shows — a gender pay gap similar to that in the United States" (Miller 2018). The author further writes, "Children hurt 
mothers' careers. This is, in large part, because women spend more time on child rearing than men do, whether by choice or not." That's a gendered role in place, a sign of high masculinity. The author notes that men's pay is not affected by the birth of a child. This study also found that Women without children are paid almost $40 \%$ more than women with children. This is insulting because we are already behind the men by $20 \%$. This is everywhere, not just in the United States (Miller 2018).

Hypothesis 1. In a country with high masculinity, gender pay gap increases.

\subsection{Individualism/Collectivism and the Wage Gap}

IDV is the extent to which people feel independent, as opposed to being interdependent as members of larger wholes. Individualism does not mean egoism. It means that individual choices and decisions are expected. Collectivism does not mean closeness. It means that one "knows one's place" in life, which is determined socially. With a metaphor from physics, people in an individualistic society are more like atoms flying around in a gas while those in collectivist societies are more like atoms fixed in a crystal (Hofstede 1980).

A self-imposed cultural barrier that women naturally erect that can interfere with economic potential is putting others above themselves. I am one woman who will attest that this is true. I'm finishing my college degree years after graduating high school because I choose to stay home and raise children. But did I choose that or did I subscribe to in-group behavior?

Now that time has passed and afforded me the ability to look back over my life and question the decisions I made, coupled with the knowledge I have gained from this study, I see that it is highly likely that my in-group association influenced my choices. I welcomed and followed the beliefs of that in-group which was that kids were better at home with their mother. 
So, I willingly sacrificed my financially independence because it felt more harmonious overall for everybody if I stayed home. Interestingly, when I returned to the workforce, the very women who sustained their careers despite having children had become my superiors.

Hypothesis 2. In a country with high individualism, gender pay gap reduces.

\subsection{Power Distance and the Wage Gap}

PDI is the extent to which the less powerful members of organizations and institutions (like the family) accept and expect that power is distributed unequally. This power distance lies with the people at the bottom and not with the people at the top (Hofstede 1980).

People of all nations accept the fact that power exists. We acknowledge that there are individuals who make decisions for others. The experience with power started with the family unit, as there was a person who was the decision maker for that group. As we age, we have encounters with people in various roles that clearly have a form of power over us that is accepted such as teachers, law enforcement, and members of the legislature. Power in of itself is fundamental and necessary for ordered living. Where we differ is in how (we) collectively look at power. When different levels of power are evident, do we accept that this power is unquestionably right and should go unchallenged or do we feel that we have the right to speak truth to power and tame it? Furthermore, to what degree do we expect the powerful to be sovereign and or manageable so that we have a sense of autonomy where we can place controls on that power (Hofstede 1980).

In the study of National Culture and Service Quality (Yayla-Kullu et al., 2015) the comparison of airplane loss rate is an excellent example of the impact of national culture. In this study, Korean Air's loss rate was 4.8 and United Airline's, an American company was 0.3. 
Yayla-Kullu et al., (2015) report the reason, "The airplane 'loss rate'," primary reason because employees' cultural conditioning is not to contradict their superiors" (Yayla-Kullu et al., 2015). The co-pilots were unable to assert themselves because it would contradict their captain's actions. Interestingly, Korea has a very weak IDV of 18 (Hofstede Insights, 2017), and the United States 91 (Hofstede Insights 2017). “The Korean Air employees' cultural norms strongly discouraged the challenging of authority, even in the face of eminent danger..." (Yayla-Kullu et al., 2015).

Members of the armed forces expect to be directed by a command hierarchy and accept whatever circumstances that their rank places them in. Seniority is superior and orders are carried out without question. Also, a soldier's acceptance to follow their commander and/or life risking orders to their death and their rejection of defection to escape, are all examples of a highpower distance dimension. High PDI cultures organize their societies into class structures and people accept as normal the bottom position that they find themselves born into; along with the resulting circumstances.

Using Geert Hofstede's definition of Power Distance, “the extent to which the less powerful accept that power is distributed unequally" (Hofstede 1980), we are looking to see to what extent, that for instance, the attitude of non-questioning of authorities translates into questioning a boss's decision or accepting the control they have will to determine career trajectory and vice versa. Does the female demand an explanation from their boss or do they negotiate and ask for what they want, even demand it? In a country with low power distance such as Iceland with a PDI 30 (Hofstede Insights 2017), a woman would expect to be given a fair wage for a day's work and would not easily accept having to work until nearly the middle of the 
year to attain the same wage as a man. (Fortune 2017). Whereas Russia with a PDI 93 (Hofstede Insights 2017), ranks second in Top 20 countries with the biggest percentage pay gaps on MoveHub (MoveHub 2017).

Hypothesis 3. In a country with high power distance, gender pay gap increases.

\subsection{Uncertainty Avoidance and the Wage Gap}

UAI deals with a society's tolerance for uncertainty and ambiguity. It has to do with anxiety and distrust in the face of the unknown, and conversely, with a wish to have fixed habits and rituals, and to know the truth (Hofstede 1980).

Uncertainty avoidance per Geert Hofstede is the extent to which members in a society

feel uncomfortable when ambiguity occurs and tries to avoid it (Hofstede 1980). An example of this is women staying in jobs that affect their health because it's what they are used to. France has a high UAI index of 86 (Hofstede Insights 2017). Some women in France are suffering from an invisible occupational disease. This condition affects workers with repetitive duties who incur injury due to the neglect of care they receive in their work environment. It's further aggravated by the dismissal of their injuries by management. According to Rachel Saada, an expert on labor law in France these are, “...stresses the ambiguities” (Equal Times 2018). Labor doesn’t recognize the impact to women's health or financial sustainability because they don't have a concrete process for addressing the dangers in "women's work." The avoidance of the term hardship and how it applies to work that women do is causing the problem (Equal Times 2018).

How this could also show up as impacting women's wages is when a superior, manager, or boss turns down a project proposal. The newness of the idea may feel threatening and thus they may reject the idea. Another way this can show up is when the superior in a work 
relationship will not delegate to subordinates. This controlling attitude is a factor in high uncertainty avoidance and can limit exposure to new skills and mentors and circles of influence.

As you can see women's wage gap can go beyond gender bias and can be steeply rooted in cultural attitudes. This could be a reason why efforts to reduce the gap have failed, as it is often viewed from the lens of discrimination. Factors such as cultural dimensions need to be explored to see how something as simple as just the fear of doing something unknown can impact women's economic potential as well. Uncertainty avoidance is also a cultural thing that women need to learn how to navigate through using strategies and techniques. Exploring the culture more thoroughly and understanding how to successfully deal with this dimension is an essential skill to learn.

Hypothesis 4. In a country with high uncertainty avoidance, gender pay gap increases.

\section{Data and Methods}

We use regression to test our hypotheses. Our data come from two sources: Hofstede's national culture dataset was merged with the 2016 Global Gender Gap Report "Overall Index" data set. Resulting regression model shows the significant relationships between the gender gap and national culture dimensions.

\subsection{Geert Hofstede's Framework for Assessing Culture}

“A large research project, involving 116,000 questionnaires, about the work-related value patterns of matched samples of industrial employees in 50 countries and three regions at two points in time. Half of the variance in the countries' mean scores can be explained by four basic dimensions, here labeled power distance, uncertainty avoidance, individualism versus collectivism, and masculinity versus femininity. These dimensions are offered as a framework 
for developing hypotheses in cross-cultural organization studies. Index scores of the countries on the four dimensions correlate significantly with the outcomes of about 40 existing comparative studies" (Hofstede 1980).

\subsection{The Global Gender Gap Report 2016 - World Economic Forum.}

The Global Gender Gap Report (GGGR) is developed by the World Economic Forum (WEF) and benchmarks 144 countries on their progress towards gender parity across four dimensions, health, education, economy and politics. The report tracks the gaps between men and women. The index rates countries on a score from 0 to 1 with the highest possible score 1 (equality) and the lowest possible score is 0 (inequality).

The 2016 GGGR shows there's still inequality across the board. Per the 2016 report, "there are only five countries that have closed $80 \%$ of the gap or more. In addition, there are 64 countries that have closed between $70 \%$ and $80 \%$ of their gender gap. A further 65 countries have closed between $60 \%$ and $70 \%$, while 10 countries have closed between $50 \%$ and $60 \%$. In 2016, no country had closed less than $50 \%$ of their overall gender gap. However, there is wide variety in progress on closing the gender gap in every world region, with both success stories and underperforming countries in each" (GGGR 2016). Also, in 2016, "the average progress on closing the global gender gap stands at a score of 0.683 - meaning an average gap of $31.7 \%$ remains to be closed worldwide across the four Index dimensions in order to achieve universal gender parity" (GGGR 2016). 
According to the report, "only $59 \%$ of the economic participation gap has been closed-a continued reversal on several years of progress and the lowest value measured by the Index since 2008” (GGGR 2016).

\begin{tabular}{lr}
\multicolumn{2}{c}{ 4. Results and Discussions } \\
\hline \multicolumn{2}{c}{ Regression Statistics } \\
\hline Multiple R & 0.612839608 \\
R Square & 0.375572385 \\
Adjusted R Square & 0.342707774 \\
Standard Error & 0.047945333 \\
Observations & 81 \\
\hline
\end{tabular}

ANOVA

\begin{tabular}{|c|c|c|c|c|c|}
\hline & $d f$ & $S S$ & $M S$ & $F$ & $\begin{array}{c}\text { Significance } \\
F\end{array}$ \\
\hline Regression & 4 & 0.10507946 & 0.026269865 & 11.42786635 & $2.5835 \mathrm{E}-07$ \\
\hline Residual & 76 & 0.17470538 & 0.002298755 & & \\
\hline \multirow[t]{2}{*}{ Total } & 80 & 0.27978484 & & & \\
\hline & Coefficients & $\begin{array}{l}\text { Standard } \\
\text { Error }\end{array}$ & t Stat & $P$-value & \\
\hline Intercept & 0.783 & 0.034 & 22.723 & 0.000 & $* * *$ \\
\hline pdi & -0.00064 & 0.000 & -1.898 & 0.061 & $*$ \\
\hline idv & 0.00071 & 0.000 & 2.271 & 0.026 & $* *$ \\
\hline mas & -0.00083 & 0.000 & -2.951 & 0.004 & $* * *$ \\
\hline uai & -0.00038 & 0.000 & -1.526 & 0.131 & NS \\
\hline
\end{tabular}

Our research found evidence for the three of four hypotheses, namely PDI, IDV, and MAS. It also found inverse relationships between three of the dimensions and their respective gender parity index scores. R square was significant for all but one dimension, UAI. Further explanation will be in the discussions below. 


\subsection{Masculinity and Global Index Scores}

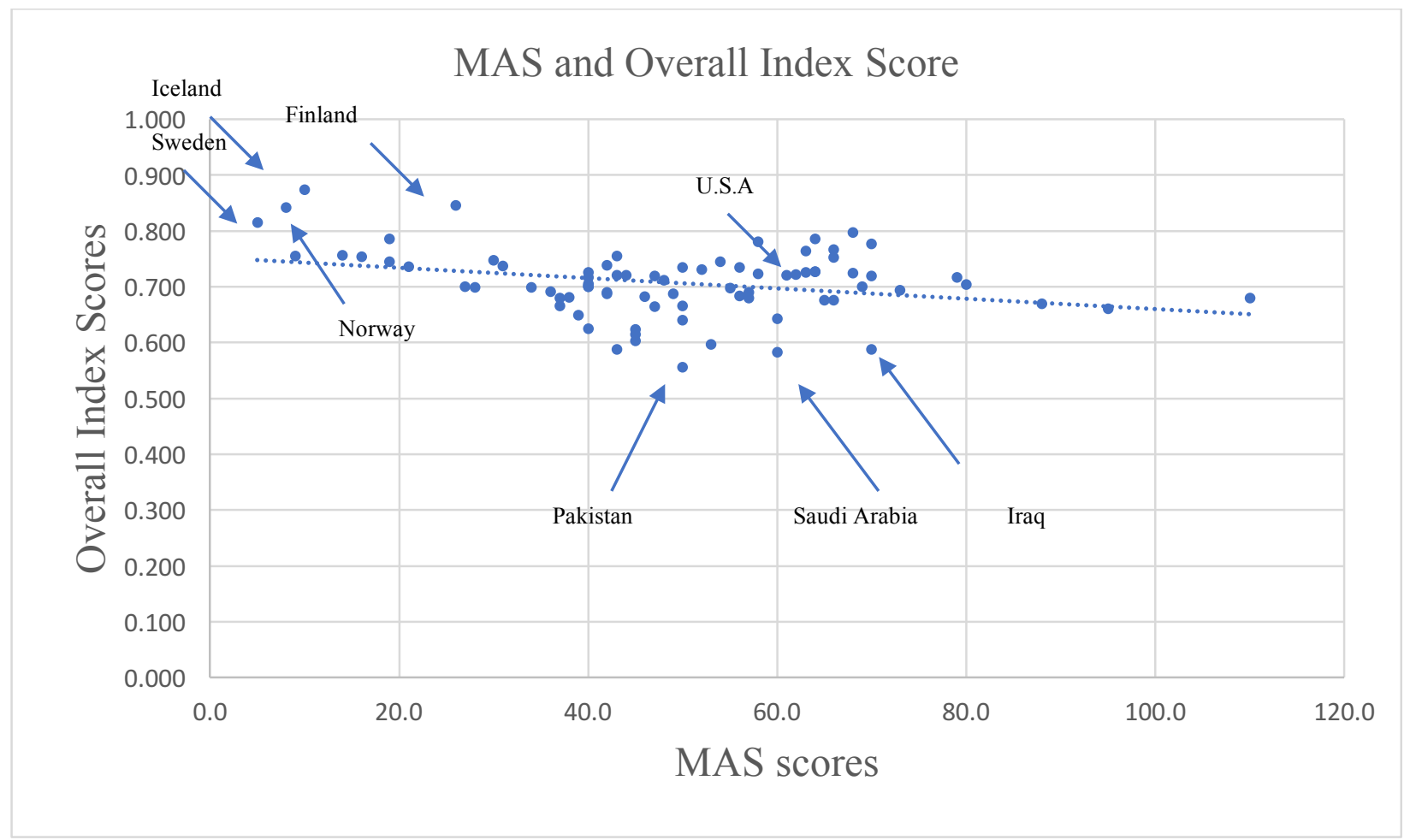

Figure 1: Masculinity and Global Index Scores

Hypothesis 1 . In a country with high masculinity, gender pay gap increases.

We posit that as the masculinity dimension decreases, the gap in pay between men and women also decreases. Our findings confirm the hypothesis. The statistical result for MAS is significant at $p=.004$ and find that there is an inverse relationship between MAS and gender parity.

As the societal culture of masculinity increases, the gender pay gap widens. A high MAS index is the sociocultural dimension that assumes that individuals born male or female have innate thoughts and behavior that are either masculine or feminine respectively. The masculine culture believes that masculinity and femininity have distinct societal roles. Masculine culture 
stresses winning. Competition, achievement and success are important in masculine culture. A low score on this dimension equates to a feminine quality that is driven by nurture and caring and the valuing of the quality of life. The regression model validates the correlation between female wages and masculinity in a culture.

\begin{tabular}{|c|c|c|}
\hline Country & MAS & $\begin{array}{c}\text { Overall Index } \\
\text { Score }\end{array}$ \\
\hline Russia & 36.0 & 0.691 \\
\hline
\end{tabular}

Russia has a MAS score of 36 (Hofstede Insights 2017) and closed on 69\% of their labor market participation gender gap (World Economic Forum 2016). Women in masculine cultures experience employment discrimination because of societal gender roles. In Russia, there are jobs classified as too hard for women and protective laws preventing women from working at specified hours of the day, predominantly after midnight. Some Russian women have been able to get around the limits to the time of day they can work through temporary job contracts but it's not a permanent solution. (Paranyushkin 2015)

According to the Human Rights Watch, "gender-specific protective legislation and mandated benefits in Russia deny women the ability to compete for work on equal terms with men. Rather than allow women to choose where to work, the state has determined that women are unfit for certain jobs, or that certain types of employment are inappropriate for women.” (Human Rights Watch 1995). In contrast, for men, it is believed that becoming husbands and/or fathers, is a status that makes them more ambitious. (Henderson 2018). And thus, more suited for harder work. 


\begin{tabular}{|c|c|c|}
\hline Country & MAS & $\begin{array}{c}\text { Overall Index } \\
\text { Score }\end{array}$ \\
\hline Iceland & 10.0 & 0.874 \\
\hline
\end{tabular}

Iceland has a MAS score of 10 (Hofstede Insights 2017) and closed on $87 \%$ of their labour market participation gender gap (World Economic Forum, 2016). Iceland set legislation in place that opposes gender specific discrimination. They are the first country to make pay inequality illegal. Starting January 1,2018 , fines will be assessed close to $\$ 500$ a day to companies that cannot prove the equal pay exists. This is the first time that fines for failing to meet standards of equality were imposed. (BBC 2018). Furthermore, In Iceland women are expected to enter professions generally considered to be men's jobs and have those rights protected "It wants to completely eliminate the pay gap within five years, and already requires company boardrooms to have at least 40 percent female representation by law." (Alastair Jamieson 2018). 


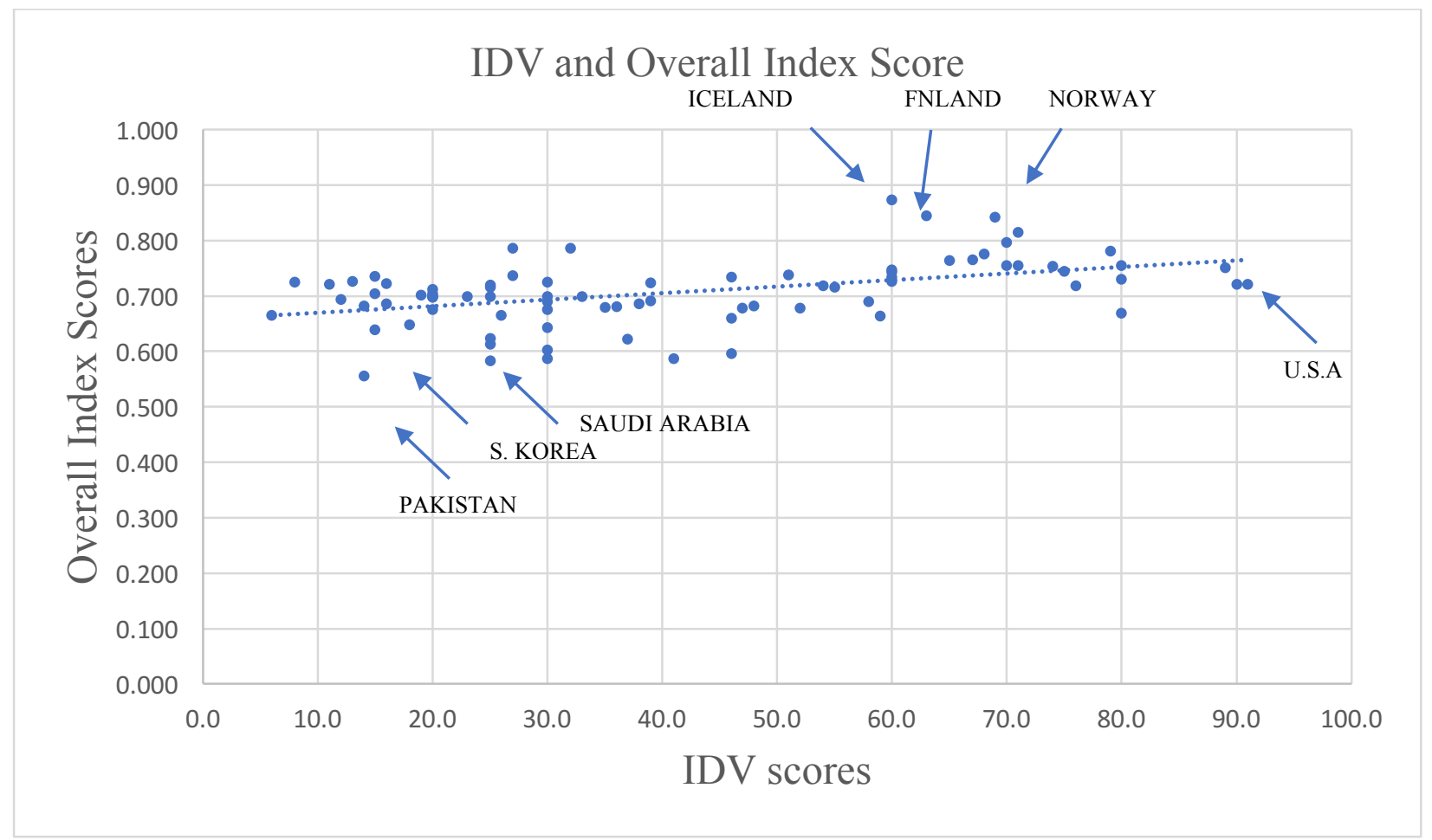

Figure 2: Individualism and Overall Index Scores

Hypothesis 2. In a country with high individualism, gender pay gap reduces.

We posit that as IDV increases, the gap in pay between men and women decreases. Our findings confirm the hypothesis. As individualism increases the gender pay gap reduces. In cultures where individual choices and decisions are expected, female wages increase. A distinctive in-group association does appear to reduce the amount of a female wages. As collectivism does not mean closeness. It means that one "knows one's place" in life, which is determined socially. If women's work is believed to be set by some arbitrary notion, then the expectation is that those in the culture of low IDV would feel it's their place to accept the different amount. The regression model validates the correlation between female wages and individuality in a culture. 


\begin{tabular}{|c|c|c|}
\hline Country & IDV & $\begin{array}{c}\text { Overall Index } \\
\text { Score }\end{array}$ \\
\hline U.S.A. & 91.0 & 0.722 \\
\hline
\end{tabular}

United States has one of the highest IDV scores of 91 (Hofstede Insights 2017) and closed on $72 \%$ of their labour market participation gender gap (World Economic Forum 2016). The independent American spirit wants no one to hold them down as they reach for the "American dream." However American women are being denied the realization of the dream due to the individualistic spirit that permeates the United States because it prides itself on personal responsibility. In the American culture, individual families are responsible for taking care of their immediate families; community services can be accessed but in limited amounts if there is significant need for them. This cultural dynamic does not lean itself toward developing programs that share the cost of personal decisions such as starting a family. And that's significant because 81 percent of all women become moms, says "Kristin Rowe-Finkbeiner, CEO and executive director of MomsRising (Corbett 2018).

Women need an infrastructure of care to thrive financially. A caring support system "understood as any activity that involves investment in others rather than ourselves" (Slaughter 2018). The United States lags behind other developed countries in the provision of paid maternity leave and affordable childcare. The cost of childcare alone drives many women out of the workforce. Unpaid care is a leading reason why women don't receive equality in the workplace. Women of all socioeconomic structures are impacted by childcare costs but the middle class is the most affected. "Barely able to survive on one wage but still expected to put in 
the "second shift" of care work after their first shift of paid work is over" (Slaughter 2018). According to Harvard economist Claudia Goldin, "the wage gap is largest for American women in their 30's (Cliff 2017), that's a women's prime, childbearing years.

American culture does not have favorable policies nurturing the family. Again, children, for the most part, are considered the families problem and not an employer's responsibility. Also, women departure from the workforce is more likely then men's because on average, men's incomes are higher, so unless paid leave is compensated in full, families make the decision that it's less costly to lose the woman's income than the man's. Furthermore, once a woman leaves the workplace or reduces her work hours to care for children, her chances of staying on pace with men's pay, decreases even further.

Interest groups such as Family Values @Work are working to implement changes in policies at the state and federal level but currently only New Jersey, New York, California and Rhode Island have policies adopted to support fathers and mothers in paid family leave. (Family Values at Work 2016).

"While all women are subject to economic discrimination, race and ethnicity are also factors in determining pay. Compared to the white man's dollar, white women earn $\$ 0.79$ and Asian women $\$ 0.87$. Minority groups battle even worse inequality, with black women earning $\$ 0.63$ per every dollar that white men are paid, Native American women $\$ 0.57$, and Latina women $\$ 0.54$ (Fair Observer 2018). The wage gap in the U.S. may be smaller than other countries but the lack of support decreases the value of the wages that are earned and this is significant considering American women make 22\% less per hour than men (Fair Observer 2018). 
Workplace sexual misconduct is yet another cultural phenomenon that reduces a women's wages. The United States has their fair share of scandals in Hollywood alone to confirm the statistics. Though we have the \#MeToo movement in full force, there is still negative impacts to careers felt by women who defend themselves. When a woman uncovers the sexual harassment that is occurring within the group, there are risks involved. The possibility of a disruption of their career trajectory is a major setback. Wages and compensation are affected all for denying the unwanted advances of others. In addition, the disruption of career trajectory due to leaving a job to escape harassment instead of speaking up, is a damaging impact as well. "In the 2017 fiscal year alone, Americans filed 12,428 sex-based workplace complaints with the EEOC, and about half of those involved sexual harassment. The agency is aware of at least 1,175 employees who left their jobs last year as a result of the reported incidents" (Corbett 2018). 


\subsection{Power Distance and Global Index Scores}

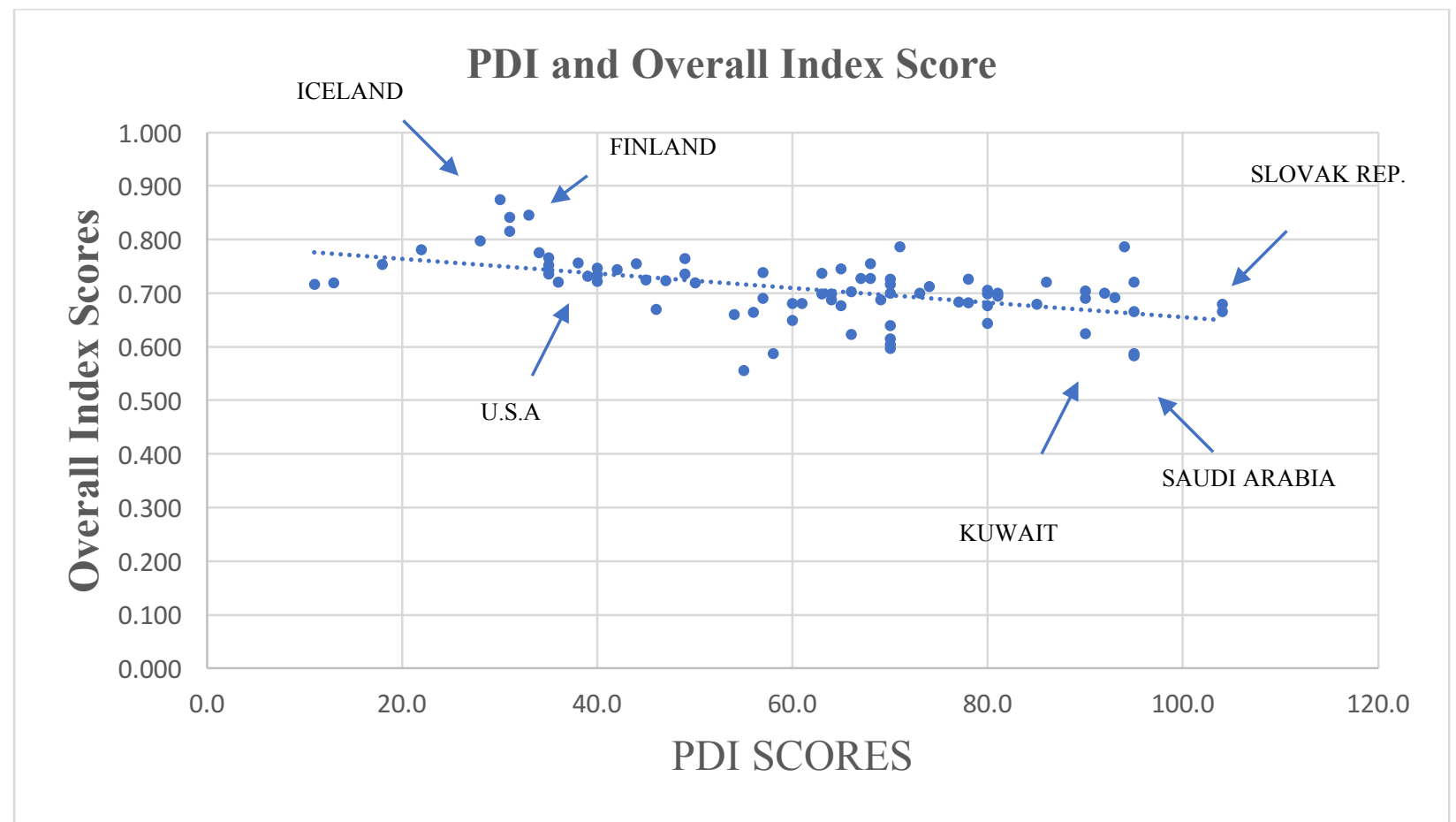

Figure 3: Power Distance and Overall Index Scores

Hypothesis 3 . In a country with high power distance, gender pay gap increases.

We posit that as PDI decreases, the gap in pay between men and women also decreases. Our findings confirm the hypothesis. The statistical results for PDI are significant at $\mathrm{p}=.06$ and find that there is an inverse relationship between PDI and gender parity. Countries with the lowest levels of power distance have the smallest gender pay gap. Scandinavian countries by far have the least power distance in their culture. Middle Eastern countries have some of the larger distances in power amongst the indexed countries. Interestingly, Israel at $13 \%$ ranks lower than Iceland, Norway and Sweden (Hofstede Insights 2017). The results match the expectation reasoning that people who accept and expect that power is distributed unequally will accept a 
disparity in the levels of pay and see a lager difference in gender gap. The regression model validates the correlation between female wages and power distance in a culture.

\begin{tabular}{|l|l|l|}
\hline Country & PDI & $\begin{array}{l}\text { Overall Index } \\
\text { Score }\end{array}$ \\
\hline Mexico & 81.0 & 0.700 \\
\hline
\end{tabular}

Mexico with a PDI score of 81 (Hofstede Insights 2017) signifies a large power distance culture and are only closing on $70 \%$ of their labor market participation gender gap (World Economic Forum, 2016). According to the Organisation for Economic Co-operation and Development (OECD) Mexico has one of the largest gender employment gaps in the OECD.

Working women in Mexico on average are employed in low paying jobs with few social protections (OECD 2017). "Gender stereotypes and discrimination continue to restrict women's choices, and women perform over 75\% of all unpaid housework and childcare," (OECD 2017 report Chapter 15). Furthermore, "Only 44.9\% of working-age Mexican women are employed. This is the third lowest female employment rate in the OECD, after Turkey (28.7\%) and Greece (41.7\%), and well below the OECD average of $60.1 \%$ of women. Mexican men, in contrast, have relatively high employment rates ( $78.5 \%$ of men are employed), leading to one of the largest gender gaps in employment in the OECD” (OECD 2017 report Chapter 11). Turkey's PDI index score is 66 and Greece 60 (Hofstede Insights 2017). 


\begin{tabular}{|l|c|c|}
\hline Country & PDI & $\begin{array}{c}\text { Overall Index } \\
\text { Score }\end{array}$ \\
\hline Netherlands & 38.0 & 0.756 \\
\hline
\end{tabular}

Netherlands with a PDI score of 38 (Hofstede Insights 2017) has closed on 75.6\% of their labor market participation gender gap (World Economic Forum 2016). Heineken operates 7 breweries in Mexico with the most recent opened February 27, 2018 in Meoqui, Chihuahua, Mexico. (Heineken 2018). Employees from Mexico's head-office who transfer to the headquarters of Heineken in Amsterdam are experiencing a culture shock managing the Dutch people. In Mexican culture individuals with power are superior beings and shown a deference of respect. In Dutch culture, the employees do not care who the boss is and will challenge them, they do not assume they will be simply told what to do. The Dutch culture has a very low PDI score of 38 and expect to be part of the leadership's decision making process (Hofstede Insights 2017). Mexican employees in leadership are finding themselves unaccustomed to the environment and unprepared to handle the confrontation. (Meyer 2014). 
4.4 Uncertainty Avoidance and Global Index Scores

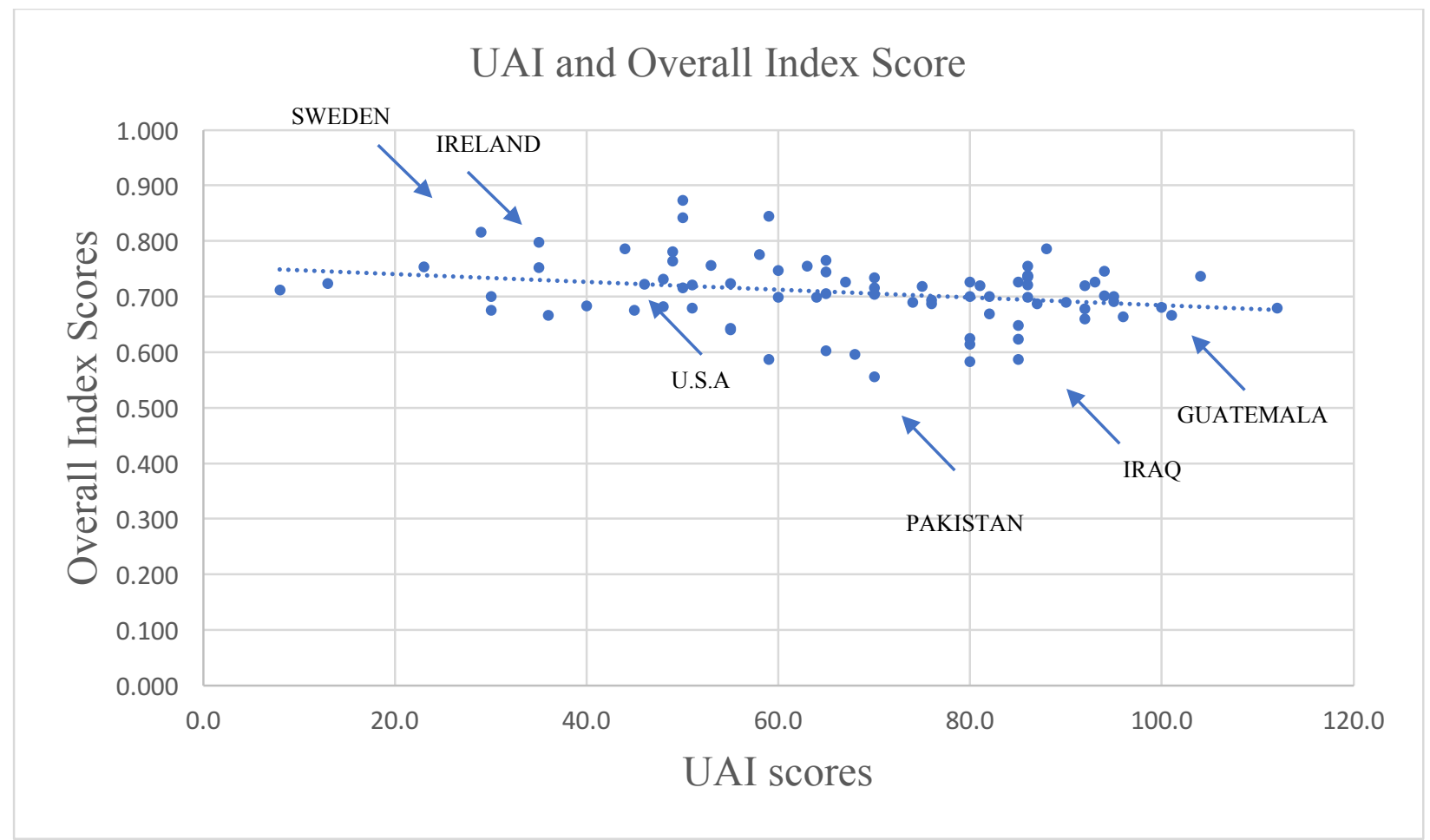

Figure 4: Uncertainty Avoidance and Overall Index Scores

Hypothesis 4. In a country with high uncertainty avoidance, gender pay gap increases.

We posit that as uncertainty avoidance decreases, the gap in pay between men and women also decreases. We could not find support for our hypothesis in this dimension. The statistical results for UAI were not significant,

UAI societies are characterized as rigid, inflexible and needing rules to help them control uncertainty and ambiguity. In the 21 st Century the world has become a smaller and scarier place yet some impractical rules still exist UAI cultures. 


\begin{tabular}{|c|c|c|}
\hline Country & UAI & $\begin{array}{c}\text { Overal Index } \\
\text { Score }\end{array}$ \\
\hline Russia & 95.0 & 0.691 \\
\hline
\end{tabular}

Russia has a high UAI index score of 95 and closed on $69 \%$ of their labor market participation gender gap (World Economic Forum 2016). Russia has explicit rules for women employment. "Pregnant women or women with a child 1 to 3 years of age are strictly forbidden to work at night. When a pregnant woman leaves her job to give birth and look after her child, there is a 'requirement for a 3 year-paid maternity leave for child care'. Therefore, young women are often discriminated when applying for a job for that reason.” (Paranyushkin 2018)

Women's pay is significantly reduced because of Russia's masculine culture for sure but also the impact of their rules is apparent. Interestingly, the abortion rate in Russia is high, where there are 38 abortions per 1,000 women of reproductive age. Could this be the Russian women's way for dealing with pay inequity? (Victor Agadjanian \& Sam Hyun Yoo 2018)

In 2000, new regulations were introduced that restricts women from 456 jobs in 38 careers. (Joe Vesey Byrne 2017). According to the International Labour Organization, the following are the legislation influencing the pay equity dilemma for women in Russia, “Government Order No. 162 of 25 February 2000," approving the official List of tasks involving heavy work and work in harmful working conditions in which the employment of women is prohibited (hereinafter "the List") was adopted" and "section 253 of the Labour Code restricts the employment of women in heavy work and work in harmful or hazardous working conditions, and in underground work, except for light (non-physical) duties or work in connection with sanitary and domestic services.” (International Labour Organization, ILO 2017), 


\begin{tabular}{|c|c|c|}
\hline Country & UAI & $\begin{array}{c}\text { Overal Index } \\
\text { Score }\end{array}$ \\
\hline Sweden & 29.0 & 0.815 \\
\hline
\end{tabular}

Sweden with a UAI score of 29 (Hofstede Insights 2017), closed on $81.5 \%$ of their labour market participation gender gap (World Economic Forum 2016). added new legislation to their Discrimination Act of 2017 which provides new measures to prevent discrimination. Salaries must be reported annually and employers much set up a system to prevent harassment, sexual harassment and retaliatory measures. ("Discrimination Act") What this means is that employers must act to promote equality between men and women and investigate where is discrimination and take action against it. These laws are considerably different than the laws in Russia and demonstrates that rules can exist that facilitate women's empowerment. And though the Swedish women still aren't paid the same as men, they do have the opportunity to pursue employment of their choice for the main part and their welfare system removes the barrier of unpaid leave affording women of childbearing age more opportunity to thrive financially. 
5. Workforce participation by industry.

\begin{tabular}{|c|c|c|c|c|c|c|c|c|c|c|c|c|}
\hline \multirow[b]{2}{*}{ Industry group } & \multirow[b]{2}{*}{ CEOS } & \multirow[b]{2}{*}{$\begin{array}{l}\text { Boerd } \\
\text { members }\end{array}$} & \multicolumn{2}{|c|}{ Senior roles } & \multicolumn{2}{|c|}{ Mid-level roles } & \multicolumn{2}{|c|}{ Junior roles } & \multicolumn{2}{|c|}{ Line roles } & \multicolumn{2}{|c|}{ Staff roles } \\
\hline & & & Cument & 2020 & Current & 2020 & Current & 2020 & Current & 2020 & Current & 2020 \\
\hline Industries Overall & $9 \%$ & $28 \%$ & $15 \%$ & $25 \%$ & $24 \%$ & $33 \%$ & $33 \%$ & $36 \%$ & $30 \%$ & $34 \%$ & $35 \%$ & $39 \%$ \\
\hline Basic and Infrastructure & 2 & 35 & 9 & 17 & 13 & 21 & 22 & 29 & 14 & 23 & 20 & 27 \\
\hline Consumer & 10 & 21 & 16 & 24 & 26 & 33 & 33 & 37 & 31 & 34 & 37 & 41 \\
\hline Energy & 0 & 32 & 11 & 20 & 19 & 27 & 24 & 27 & 19 & 25 & 22 & 30 \\
\hline Financial Services \& Inwestors & 9 & 19 & 20 & 30 & 33 & 40 & 43 & 43 & 35 & 39 & 42 & 43 \\
\hline Healthcare & 6 & - & 15 & 28 & 31 & 44 & 39 & 46 & 44 & 49 & 41 & 48 \\
\hline Information and Communication Technology & 5 & 19 & 11 & 20 & 21 & 29 & 32 & 34 & 23 & 32 & 33 & 38 \\
\hline Media, Entertainment and Information & 13 & 22 & 25 & 33 & 25 & 32 & 35 & 36 & 38 & 43 & 47 & 46 \\
\hline Mobility & 9 & 17 & 13 & 21 & 21 & 30 & 28 & 33 & 25 & 31 & 34 & 36 \\
\hline Professional Services & 9 & 23 & 22 & 34 & 33 & 40 & 39 & 43 & 44 & 44 & 44 & 46 \\
\hline
\end{tabular}

Source: Future of Jobs Survey, World Economic Forum.

Figure 5: Gender gap and female share of customer base, by industry 
Gender gap and female share of customer base, by industry

Share of female workforce, \%

\begin{tabular}{|c|c|c|c|c|c|c|c|c|c|c|}
\hline \multirow[b]{2}{*}{ Industry group } & \multirow[b]{2}{*}{$\begin{array}{l}\text { Shere of } \\
\text { women }\end{array}$} & \multirow[b]{2}{*}{$\begin{array}{c}\text { Gender } \\
\text { wage gap }\end{array}$} & \multicolumn{2}{|c|}{$\begin{array}{l}\text { Relative ease } \\
\text { of recrultment }\end{array}$} & \multicolumn{2}{|c|}{$\begin{array}{l}\text { Business to } \\
\text { business }\end{array}$} & \multicolumn{2}{|c|}{$\begin{array}{l}\text { Business to } \\
\text { consumer }\end{array}$} & \multicolumn{2}{|c|}{$\begin{array}{l}\text { Business to } \\
\text { government }\end{array}$} \\
\hline & & & Current & 2020 & Ourrent & 2020 & Cument & 2020 & Current & 2020 \\
\hline Industries Overall & $30 \%$ & $32 \%$ & -0.74 & -0.11 & $25 \%$ & $33 \%$ & $31 \%$ & $33 \%$ & $21 \%$ & $27 \%$ \\
\hline Basic and Infrastructure & $16 \%$ & $35 \%$ & -0.99 & -0.20 & $16 \%$ & $28 \%$ & $26 \%$ & $30 \%$ & $18 \%$ & $24 \%$ \\
\hline Consumer & $33 \%$ & $49 \%$ & -0.63 & -0.35 & $14 \%$ & $18 \%$ & $47 \%$ & $49 \%$ & $11 \%$ & $15 \%$ \\
\hline Energy & $19 \%$ & $31 \%$ & -1.08 & 0.14 & $18 \%$ & $23 \%$ & $26 \%$ & $26 \%$ & $18 \%$ & $19 \%$ \\
\hline Financial Services \& Investors & $36 \%$ & $38 \%$ & -0.78 & -0.11 & $25 \%$ & $34 \%$ & $39 \%$ & $41 \%$ & $19 \%$ & $29 \%$ \\
\hline Healthcare & $51 \%$ & $15 \%$ & -0.09 & -0.10 & $50 \%$ & $43 \%$ & $57 \%$ & $57 \%$ & $60 \%$ & $60 \%$ \\
\hline Information and Communication Technology & $24 \%$ & $25 \%$ & -0.91 & -0.39 & $25 \%$ & $33 \%$ & $24 \%$ & $30 \%$ & $17 \%$ & $21 \%$ \\
\hline Media, Entertainment and Information & $37 \%$ & $18 \%$ & -0.67 & 0.28 & $20 \%$ & $32 \%$ & $48 \%$ & $44 \%$ & $15 \%$ & $19 \%$ \\
\hline Mobility & $19 \%$ & $39 \%$ & -0.92 & -0.04 & $21 \%$ & $30 \%$ & $21 \%$ & $27 \%$ & $16 \%$ & $19 \%$ \\
\hline Professional Services & $40 \%$ & $22 \%$ & -0.39 & -0.09 & $31 \%$ & $45 \%$ & $32 \%$ & $30 \%$ & $20 \%$ & $28 \%$ \\
\hline
\end{tabular}

Source: Future of Jobs Survey, World Economic Forum.

Note: Fielative ease of recruitment measured on a quaitative -2 ("much harder") to +2 ("much easier") scale. Gender wage gap reters to share of responses in the attrmative.

Figure 6: Women's workforce participation, by industry

Figures 5 and 6 show the role that sectoral participation of women plays in national workforce.

Policies at work impact women's job placement and opportunity for advancement.

"Across all industries, women currently make up on average 33\% of junior level staff, $24 \%$ of mid-level staff, $15 \%$ of senior level staff and $9 \%$ of CEOs. Having invested in women as they enter in junior positions, employers appear to frequently lose their investment by failing to retain talent up the ladder. The industries with the lowest junior level intake also expect more dramatic drop-offs along the talent pipeline, with low intake at the junior level translating to similar underperformance later on. The participation of women in line and staff roles highlights some of the additional barriers to progressing to top level positions. Women are under-represented in line roles in the Mobility, Information and Communication Technology, Energy and Basic and Infrastructure sectors, with line roles more likely to equip women with the skills and experience 
that would prepare them for senior positions. Projecting their figures for the year 2020, companies expect some improvement, spread unevenly across different industries" (weforum.org 2016).

\section{Conclusions}

The economic status of women is a global issue. The cause of the wage gap is still actively researched and efforts to reduce it sought out. There have been some achievements towards the reduction of the differences in pay between men and women in small segments of society however a gap remains and appears to be growing. An aspect to consider is the impact that cultural norms and attitudes have on the gender wage gap throughout the world. As mentioned before, discrimination alone is not the only reason women fail to be paid the same as men, it is believed that there are cross cultural barriers causing wage inequality as well. Cultural attitudes about motherhood, gender equality, what is deemed as women's work can vary based on the country. The influence of cultural norms also impacts women's negotiation skills and their ability to ask for a raise both which directly affect a women's economic empowerment. This research examined the pay equity dilemma women face around the world and how it is different in various regions of the world.

In cultures with low masculinity, a reduced gender pay gap was validated. Masculinity is so prevalent that gender specific work roles are legislated in some highly masculine cultures such as in Russia. In comparison, Iceland is proving that legislation protecting women from gender specific discrimination can be instituted successfully and improve the economic position of women. 
In cultures with high individualism, a reduced gender pay gap was validated. The impact of unpaid care is significant because the cost of childcare is driving women out of the workplace. Women need an infrastructure of care to thrive financially. Without support, women don't receive equality in the workplace. An individualistic culture typically does not support developing programs that share the cost of personal decisions such as starting a family. Race and ethnicity are also factors in determining pay. The United States the country with the lowest power distance in our research has closed on $72 \%$ whereas Guatemala $66 \%$.

In cultures with low power distance, a decrease in the gender pay gap was validated. On the average, women are employed in low paying jobs with few social protections. Men, on the other hand, assume they are entitled to the best jobs. Iceland with low power distance culture closed on $87 \%$ of their gender pay gap whereas the Slovak Republic with high a power distance culture closed on $68 \%$.

In cultures with low uncertainty avoidance, we could not find support for our hypothesis in this dimension, however, where the uncertainty avoidance dimension is dominant, explicit impractical rules for women employment seem to exist. Rules which are discriminatory and impede women's chances for economic independence. In contrast, low uncertainty avoidant cultures also have laws, except their legislation provides measures to prevent discrimination such as the Discrimination Act of 2017 in Sweden who has closed on 82\% of their labour market participation gender gap in comparison to Greece at $68 \%$.

A global society is emerging exposing all nations to new cultural dimensions. Citizens in cultures that are in direct opposition to the incoming trends of equality will need to decide whether to follow in the footsteps of their deep-rooted traditions or venture into the new world of 
expanding opportunity. Today we still see a world where men hold higher paying roles than women. Cultural characteristics do affect pay equity. The Korn Ferry Gender Pay Index, "study found that globally men are paid on average 16.1\% more than women.” (Business Today 2018). However, the future is looking brighter as the same study also found that when we compared women and men in the same job, the gap significantly reduces.

Experts don't really agree on what will solve the gender wage gap but many solutions are being sought. On the bright side, several solutions are actively being pursued. There's evidence on the positive affect that public expenditure on families has on societies. This can help to influence law makers to make more benefits available resulting in a reduction of the gender gap. NAFTA renegotiations are presenting Mexico, Canada and the US with an opportunity to economically, politically and socially improve women's rights. Support for gender concerns include discussions for Labor Protections and Equal Pay if the U.S. can be convinced to accept gender as a component of NAFTA (Center for Feminine Foreign Policy 2017). Additionally, the U.S. is pursuing legislative efforts such as allowing employees to discuss pay, increasing the options of affordable child-care and expanding paid family leave (Wall Street Journal 2017).

In addition to legislation, we need a cultural shift. What is taught about women in the home must change since this is the birthplace of culture. Also, helpful are men assuming more responsibility of being nurturers and consistent communication messages sent out in support of community to influence attitudes and foster a more empathetic society. There are varied solutions for closing the gender wage gap and it will be fascinating to see what the inevitable collision of ideas will manifest in the terms of pay equity for women around the world. 


\section{REFERENCES}

2017 OECD report chapter 11. The Pursuit of Gender Equality: An Uphill Battle.

https://read.oecd-ilibrary.org/social-issues-migration-health/the-pursuit-of-genderequality_9789264281318-en\#page143. Accessed 12 July 2018.

2017 OECD report chapter 15. The Pursuit of Gender Equality: An Uphill Battle.

https://read.oecd-ilibrary.org/social-issues-migration-health/the-pursuit-of-genderequality_9789264281318-en\#page191. Accessed 12 July 2018.

"3 Reasons Why the Gender Pay Gap Still Exists." Fortune, http://fortune.com/2017/04/03/equal-pay-day-2017-wage-gap/. Accessed 19 Mar. 2018.

Ahituv, Avner and Robert I. Lerman. "How do marital status, work effort, and wage rates interact?" Demography 44 (2007): 623-647.

Alastair Jamieson. Iceland wants to end its gender pay gap in 5 years. Can the U.S. follow? https://www.nbcnews.com/news/world/iceland-wants-end-gender-pay-gap-5-years-can-u-

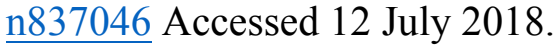

“Analysis | Oct. 26, the Day Women Start Working for Free." Washington Post, https://www.washingtonpost.com/graphics/2017/business/women-pay-gap/. Accessed 18 Mar. 2018.

Blau, Francine D., and Lawrence M. Kahn. 2017. "The Gender Wage Gap: Extent, Trends, and Explanations." Journal of Economic Literature, 55 (3): 789-865.

DOI: $10.1257 /$ jel.20160995.

Brinded, Lianna. "It's Going to Take 217 Years to Close the Global Economic Gender Gap." Quartz, 1 Nov. 2017, https://qz.com/1117632/its-going-to-take-217-years-to-close-theglobal-economic-gender-gap/.

Business Today. India fares better than US, UK, Germany in gender pay gap. https://www.businesstoday.in/current/economy-politics/india-fares-better-than-us-ukgermany-gender-pay-gap/story/275772.html Accessed 12 July 2018.

Byrne, Joe Vesey. The 456careers women war banned from doing in Russia. https://www.indy100.com/article/careers-women-banned-russia-400-captain-svetlanamedvedeva-7922641. Accessed 12 July 2018.

Carnevale, Anthony P., et al. Women Can't Win: Despite Making Educational Gains and Pursuing High-Wage Majors, Women Still Earn Less than Men. 2018. repository.library.georgetown.edu, https://repository.library.georgetown.edu/handle/10822/1049530. 
Center for American Progress. International Approach to Closing the Gender Wage Gap. https://www.americanprogress.org/issues/women/reports/2017/04/04/429825/internationa 1-approaches-closing-gender-wage-gap/. Accessed 11 Mar. 2018.

Centre for feminist foreign policy. How Mexico is Using Nafta to Promote Women's Rights. https://centreforfeministforeignpolicy.org/journal/2017/11/23/mexico-uses-nafta-to-fightfor-women Accessed 12 July 2018.

Corbett, Jessica. On Equal Pay Day, New Study Shows Wage Gap Actually Growing for Women Under 40.https://www.commondreams.org/news/2018/04/10/equal-pay-day-new-studyshows-wage-gap-actually-growing-women-under-40.

Demographic Research. Migration, legality, and fertility regulation: Abortion and contraception among migrants and natives in Russia. VOLUME 38, ARTICLE 42, PAGES 1277,1302 PUBLISHED 10 APRIL 2018 https://www.demographicresearch.org/volumes/vol38/42/38-42.pdf.

Discrimination Act. https://www.government.se/4a788f/contentassets/6732121a2cb54ee3b21da9c628b6bdc7/ oversattning-diskrimineringslagen eng.pdf Accessed 12 July 2018.

Chamberlain, Andrew et al. "New Research: Demystifying the Gender Pay Gap." Glassdoor Economic Research, 23 Mar. 2016, https:/www.glassdoor.com/research/demystifyingthe-gender-pay-gap/.

Equal Times, "The 'invisible”' Risks Facing Working Women in France." Equal Times, https://www.equaltimes.org/the-invisible-risks-facing-working. Accessed 26 Mar. 2018.

"Facts and Figures: Economic Empowerment." UN Women, http://www.unwomen.org/en/whatwe-do/economic-empowerment/facts-and-figures. Accessed 6 Apr. 2018.

Fair Observer. Women in America Are Still Fighting for Equal Pay. https://www.fairobserver.com/region/north america/equal-pay-women-america-usanews-today-43490/ Accessed 12 July 2018.

Family Values@ Work. How Much Paid Leave Can I Get? http://familyvaluesatwork.org/issues/how-much-paid-leave-can-i-get Accessed 12 July 2018.

"French Firms Face Gender Pay Gap Fines." BBC News, 7 Mar. 2018. www.bbc.com, http://www.bbc.com/news/world-europe-43320041. 
Genderinequalityv10.Pdf. http://www.jamesrockey.com/wpcontent/uploads/2017/04/genderinequalityv10.pdf. Accessed 3 Mar. 2018.

"Global Gender Pay Gap Map | Percentage Pay Gap for Men \& Women." MoveHub, 6 Mar. 2014, https://www.movehub.com/blog/global-gender-pay-gap-map/.

"Getting to Gender Equality Starts with Realizing How Far We Have to Go." Women in the Workplace Study, https://womenintheworkplace.com/. Accessed 7 Apr. 2018.

Henderson, Tim. A Different Kind of Gender Gap: Seven Places Where Women Earn More Thank Men. http://www.pewtrusts.org/en/research-andanalysis/blogs/stateline/2018/03/14/a-different-kind-of-gender-gap-seven-places-wherewomen-earn-more-than-men.

Heineken. Heineken opens new brewery in Meoqui, Mexico. https://www.theheinekencompany.com/Media/Media-Releases/Pressreleases/2018/02/2172065 Accesed 12 July 2018.

Hofstede Insights. Country Comparison. https://www.hofstede-insights.com/countrycomparison/. Accessed 11 Mar. 2018.

Hofstede, Geert. "Motivation, Leadership, and Organization: Do American Theories Apply Abroad?" Organizational Dynamics, vol. 9, no. 1, June 1980, pp. 42-63. CrossRef, doi:10.1016/0090-2616(80)90013-3.

Holmes, Kaitlin, and Danielle Corley. "International Approaches to Closing the Gender Wage Gap." Center for American Progress, https://www.americanprogress.org/issues/women/reports/2017/04/04/429825/internationa 1-approaches-closing-gender-wage-gap/. Accessed 28 Mar. 2018.

Human Rights Watch. Russia. Neither Jobs Nor Justice. State Discrimination Against Women in Russian Vol. 7, No. 5. https://www.hrw.org/reports/1995/Russia2a.htm Accessed 12 July 2018.

"Iceland Now the First Country to Enforce Equal Pay for Women and Men." BBC Three, 9 Mar. 2017, http://www.bbc.co.uk/bbcthree/article/253d8b3e-1891-43ab-8848-4a5110bda171.

The Industry Gender Gap Women and Work in the Fourth Industrial Revolution - Executive Summary. http://www3.weforum.org/docs/WEF FOJ Executive Summary GenderGap.pdf. Accessed 12 July 18. 
International Labour Organization Discrimination (Employment and Occupation) Convention, 1958 (No 111) - Russian Federation (Ratification: 1961). Individual Case (CAS) Discussion: 2010, Publication: $99^{\text {th }}$ ILC session (2010). http://www.ilo.org/dyn/normlex/en/f?p=NORMLEXPUB:13101:0::NO::P13101 COMM ENT ID:3187536.

Kliff, Sarah. The truth about the gender wage gap. https://www.vox.com/2017/9/8/16268362/gender-wage-gap-explained Accessed 12 July 2018.

Meyer, Erin. Power Distance: You Can't Lead Across Cultures Without Understanding It. https://www.forbes.com/sites/forbesleadershipforum/2014/09/25/power-distance-youcant-lead-across-cultures-without-understanding-it/\#1bc7497c459a Accessed 12 July 2018.

Miller, Claire Cain. "Children Hurt Women's Earnings, but Not Men's (Even in Scandinavia)." The New York Times. NYTimes.com, https://www.nytimes.com/2018/02/05/upshot/evenin-family-friendly-scandinavia-mothers-are-paid-less.html. Accessed 18 Mar. 2018.

The Moscow Times. Women in Russia Earn Significantly Less Than Their Male Counterparts. https://themoscowtimes.com/news/women-in-russia-earn-much-less-than-men-58950/ Accessed 14 July 2018.

OECD (2018), Gender wage gap (indicator). doi: 10.1787/7cee77aa-en (Accessed on 15 July 2018).

Paranyushkin, Dimitry. Interesting Facts about Russian Women and Women Rights in Russia. https://waytorussia.net/WhatIsRussia/Women/Facts.html Accessed 12 July 2018.

Pew Research Center. Rise in U.S. Immigrants From El Salvador, Guatemala and Honduras Outpaces Growth FromElsewhere. http://www.pewhispanic.org/2017/12/07/rise-in-u-simmigrants-from-el-salvador-guatemala-and-honduras-outpaces-growth-from-elsewhere/ Accessed 12 July 2018.

Sankar, Carol. "Why Don't More Women Negotiate?” Forbes, https://www.forbes.com/sites/forbescoachescouncil/2017/07/13/why-dont-more-women$\underline{\text { negotiate/. }}$ Accessed 19 Mar. 2018.

Slaughter, Anne-Marie. America's Lack of Paid Parental Leave Policies Hurt Middle-Class Women the Most. http://time.com/5085172/america-parental-leave-care-policies/ Accessed 12 July 2018. 
The Wall Street Journal. Gender Pay Gap Narrows Significantly for the First Time Since Recession. https://blogs.wsj.com/economics/2017/09/12/gender-pay-gap-narrowssignificantly-for-the-first-time-since-recession/ Accessed 12 July 2018.

WEF FOJ Executive Summary. The Industry Gender Gap. Women and Work in the Fourth Industrial Revolution. http://www3.weforum.org/docs/WEF FOJ Executive Summary GenderGap.pdf. Accessed 12 July 2018.

work cited. Anonymous Interview. (2017). Interview with an advisor to a member of the NAFTA renegotiation working groups. Interviewed by Nicole Figot in Mexico City on October 31st, 2017.

World Economic Forum. (WEF) The Global Gender Gap Report 2016. http://www3.weforum.org/docs/GGGR16/WEF_Global_Gender_Gap_Report_2016.pdf.

Why Thousands of Women in Iceland Left Work Two Hours Early This Week - The Atlantic. https:/www.theatlantic.com/international/archive/2016/10/iceland-women-gender-paygap/505460/. Accessed 28 Mar. 2018.

Vagianos, Alanna. Rep. Frankel: Men Must Take 'Affirmative Assertive Action'Against Sexual Harassment. https:/www.huffingtonpost.com/entry/lois-frankel-equal-payday us 5acbb797e4b07a3485e74954 Accessed 12 July 2018.

Yayla-Küllü, H. Müge, et al. Employees' National Culture and Service Quality: An Integrative Review. 2014. Service Science, vol 7, no. 1, 2015, pp1-18. Informs, http://dx.doi.org/10.1287/serv.2015.0092. 